\title{
ARFGAP3 Gene
}

National Cancer Institute

\section{Source}

National Cancer Institute. ARFGAP3 Gene. NCI Thesaurus. Code C150172.

This gene is involved in the modulation of ADP-ribosylation factor 1-mediated signaling. 